\title{
Pengembangan Media Pembelajaran Interaktif C-Bonds untuk Mendeteksi dan Mereduksi Miskonsepsi dengan Strategi Conceptual Change Text
}

\author{
Eri Zuimatus Sa'diyah, Sukarmin* \\ Program Studi Pendidikan Kimia, FMIPA, Universitas Negeri Surabaya \\ *Corresponding Author. Email: sukarmin@unesa.ac.id
}

\begin{abstract}
This research aims to analyze the feasibility of C-Bonds interactive media as a detector and reducer of students' misconceptions on chemical bonding material using the Conceptual Change Text Strategy. This research method uses research and development methods that are limited to product trials with research subjects 12 students of class XI MA Roudlotun Nasyiin. The instruments used in this research include validation sheets, observation sheets and student responses, and three tier diagnostic test. The data analysis technique of this research used descriptive quantitative. The results showed the percentage of content validation was $92.59 \%$ in the very valid category and the construct validation was $91,44 \%$ in the valid category. The results of the percentage of the questionnaires response was $91.31 \%$ and the result of the observations was $95,39 \%$ both of which were included in the very practical category. The result of the percentage shift of students' misconceptions was $87.95 \%$ with the very effective category. Judging from the results of the validation, practicality, and effectiveness, CBonds interactive media can be said to be feasible to detect and reduce student misconceptions.
\end{abstract}

\begin{abstract}
Abstrak: Penelitian ini bertujuan untuk menganalisis kelayakan media interaktif C-Bonds sebagai pendeteksi dan pereduksi miskonsepsi peserta didik pada materi ikatan kimia menggunakan strategi Conceptual Change Text. Metode penelitian ini menggunakan metode penelitian dan pengembangan yang terbatas sampai uji coba produk dengan subjek penelitian 12 peserta didik kelas XI MA Roudlotun Nasyiin. Instrumen yang digunakan dalam penelitian ini meliputi lembar validasi, lembar observasi dan respon peserta didik, serta tes diagnostic three tier. Teknik analisis data penelitian ini menggunakan deskriptif kuantitatif. Hasil penelitian diperoleh persentase validasi isi $92,59 \%$ yang termasuk dalam kategori sangat valid dan validasi konstruk 91,44\% yang termasuk dalam kategori valid. Hasil persentase angket respon 91,31\% dan hasil observasi 95,39\%, keduanya termasuk dalam kategori sangat praktis. Pergeseran miskonsepsi didapatkan persentase sebesar $87,95 \%$ termasuk dalam kategori sangat efektif. Dilihat dari hasil validasi, kepraktisan, dan keefektifan, media interaktif C-Bonds dapat dikatakan layak untuk mendeteksi dan mereduksi miskonsepsi peserta didik.
\end{abstract}

\section{Article History}

Received: 19-01-2021

Revised: 01-04-2021

Accepted: 25-08-2021

Published: 11-12-2021

\section{Key Words:}

Interactive Media, Misconception, Chemical Bonds, Conceptual Change Text.

\section{Sejarah Artikel}

Diterima: 19-01-2021

Direvisi: 01-04-2021

Disetujui: 25-08-2021

Diterbitkan: 11-12-2021

\section{Kata Kunci:}

Media Interaktif,

Miskonsepsi, Ikatan Kimia, Conceptual Change Text.

How to Cite: Sa'diyah, E., \& Sukarmin, S. (2021). Pengembangan Media Pembelajaran Interaktif C-Bonds untuk Mendeteksi dan Mereduksi Miskonsepsi dengan Strategi Conceptual Change Text. Jurnal Kependidikan: Jurnal Hasil Penelitian dan Kajian Kepustakaan di Bidang Pendidikan, Pengajaran dan Pembelajaran, 7(4), 1039-1050. doi:https://doi.org/10.33394/jk.v7i4.3443

https://doi.org/10.33394/jk.v7i4.3443

This is an open-access article under the CC-BY-SA License.

\section{Pendahuluan}

Pada kurikulum nasional, kimia memiliki kedudukan yang penting terutama dalam Ilmu Pengetahuan Alam (IPA) (Azura and Copriady, 2017). Kimia dapat dimaknai sebagai ilmu yang mengulas tentang berbagai komponen dalam kehidupan mencakup struktur, sifat, dan berbagai macam perubahan materi (Medina, 2017). Kajian ilmu kimia sangatlah banyak 
mulai dari fakta, prinsip, teori, dan hukum. Kimia juga mengkaji tentang berbagai fenomena alam yang sering ditemukan. Sebagian besar konsep-konsep dari ilmu kimia bersifat abstrak sehingga sulit diterapkan dalam kehidupan sehari-hari (Widarti, Safitri and Sukarianingsih, 2018). Selain itu. Ilmu kimia yang dipelajari direpresentasikan menjadi 3 level, yaitu submikroskopik, makroskopik, dan simbolik (Sirhan, 2007). Hal tersebut dapat menjadikan peserta didik kesulitan dalam mempelajari dan memahami ilmu kimia.

Peserta didik datang ke kelas memiliki berbagai macam pengetahuan awal (prakonsepsi). Konsepsi tersebut berasal dari pengalaman yang diperoleh peserta didik berbedabeda. Konsepsi peserta didik adalah hal terpenting pada pendidikan sains. Konsepsi awal peserta didik berpengaruh pada proses belajar mereka. Sesuai dengan konsep kimia bersifat abstrak serta perbedaan konsep awal peserta didik sehingga menyebabkan miskonsepsi mudah terjadi pada peserta didik (Armagan, Keskin and Akin, 2010).

Para ilmuwan mengartikan miskonsepsi merupakan suatu pandangan akan suatu konsep yang bertentangan, melenceng dari konsep sebenarnya. Miskonsepsi terjadi secara berkelanjutan pada setiap jenjang pendidikan (Medina, 2017). Hal tersebut terjadi karena peserta didik mengandalkan konsep awal untuk memahami suatu masalah, akibatnya peserta didik kesulitan dalam mengadopsi cara berfikir yang baru (Sari and Nasrudin, 2015). Diantara cara-cara yang dapat digunakan untuk mengidentifikasi miskonsepsi yaitu dengan menggunakan tes diagnostic. Tes yang digunakan yaitu tes diagnostik tiga tingkat. Salah satu keunggulan dari instrumen tersebut yaitu akurat dalam mendeteksi miskonsepsi yang dialami peserta didik (Azura and Copriady, 2017).

Berdasarkan beberapa hasil penelitian membuktikan bahwa ikatan kimia merupakan materi yang berpotensi besar menyebabkan miskonsepsi. Ikatan kimia merupakan konsep yang bersifat abstrak kompleks dan merupakan salah satu konsep yang mendasar. Pokok bahasan dari ikatan kimia yaitu ikatan ionik, ikatan kovalen, kovalen koordinasi molekul, dan ikatan logam (Nahum et al., 2010). Sehingga, sulit untuk dipahami peserta didik dan berpotensi untuk terjadi miskonsepsi (Sari and Nasrudin, 2015). Miskonsepsi yang tidak segera disembuhkan peserta didik akan susah memahami konsep baru yang mana berdampak buruk pada hasil belajar. Oleh karena itu, miskonsepsi harus segera diatasi (Kumalaningtias, 2019). Banyak sekali metode yang digunakan untuk mereduksi miskonsepsi dan mengubah konsepsi peserta didik, salah satunya adalah dengan strategi Conceptual Change Text (CCT) (Hesti et al., 2017).

Conceptual Change Text (CCT) merupakan teks ilmiah yang dirancang untuk mengatasi dan mereduksi miskonsepsi yang dimiliki peserta didik. CCT berbeda dari buku teks biasa karena dapat membuat peserta didik merefleksikan pemikiran mereka dan menyadari prakonsepsi yang dimiliki salah (McKenna, 2014). Terdapat 4 fase atau struktur dalam strategi conceptual change, yaitu : (1) menunjukkan konsep awal peserta didik, (2) membuat konflik kognitif terhadap konsepsi peserta didik, (3) Proses equilibrasi atau penjelasan konsep yang benar, (4) rekontruksi konsep (Perdana, Suma and Pujani, 2018).

Selain strategi dan metode yang tepat, media interaktif yang mendukung dalam proses pereduksian miskonsepsi serta meningkatkan pemahaman konsep haruslah tepat (Sukarmin, 2020). Media pembelajaran dapat dikatakan efektif dan efisien yaitu terdapat unsur audio dan visual dan bersifat interaktif. Adobe Flash merupakan program yang berfungsi untuk membuat media interaktif (Yahya, Fatoni and Walidain, 2018). Adobe Flash memiliki kemampuan untuk membuat animasi, dapat menggabungkan gambar, video, suara dalam satu kesatuan (Alfiana and Sukarmin, 2019). Kelebihan Adobe Flash yaitu mempunyai bahasa pemrograman Action Script yang mampu mendukung pembuatan media pembelajaran (Yahya, Fatoni and Walidain, 2018). 
Hasil dari pra-penelitian yang telah dilakukan di MA Roudlotun Nasyiin Kabupaten Mojokerto telah ditemukan permasalahan yang menarik untuk dikaji. Dari 12 peserta didik kelas XI, 11 orang mengalami miskonsepsi pada sub materi ikatan ion, 9 orang mengalami miskonsepsi pada sub materi ikatan kovalen, 10 orang mengalami miskonsepsi pada sub materi ikatan kovalen koordinasi. Hal tersebut disebabkan oleh beberapa sumber, yaitu dari diri peserta didik, buku teks yang digunakan, dan guru (Syahrul et al., 2015). Penyebab yang bersumber dari peserta didik yaitu konsep awal yang dimiliki oleh peserta didik berbedabeda. Selain itu, kemampuan kognitif peserta didik berbeda dalam menafsirkan konsep kimia. Penyebab yang bersumber dari buku teks yaitu peserta didik hanya memiliki referensi LKS (Lembar Kerja Siswa) saja yang mana hanya memuat ringkasan materi dan latihan soal. Selain itu, keterbatan referensi di perpustakaan yang menyebabkan daya literasi peserta didik rendah. Penyebab yang bersumber dari guru yaitu cara mengajar yang digunakan oleh guru sebagian besar bersifat ceramah. Selain itu, media pembelajaran yang digunakan kurang bervariasi.

Adapun penelitian ini bertujuan untuk menganalisis kelayakan media interaktif CBonds sebagai media pendeteksi dan pereduksi miskonsepsi yang dialami peserta didik pada materi ikatan kimia dengan menggunakan strategi Conceptual Change Text. Hasil penelitian diharapkan dapat menghasilkan suatu media interaktif yang dapat mendeteksi dan mereduksi miskonsepsi dalam materi Ikatan Kimia. Sehingga, dapat memudahkan guru dalam mengatasi miskonsepsi yang dialami peserta didik dan sebagai alternatif media yang dapat digunakan saat pembelajaran.

\section{Metode Penelitian}

Penelitian ini menggunakan Metode Research and Development (R\&D) yang berjumlah 10 tahapan. Namun, dalam penelitian ini hanya menggunakan 6 tahapan sampai tahap uji coba produk. Uji Coba produk dilaksanakan kepada 12 peserta didik MA Roudlotun Nasyiin Kabupaten Mojokerto yang telah mendapatkan materi ikatan kimia. Alur metode R\&D ditunjukkan pada Gambar 1

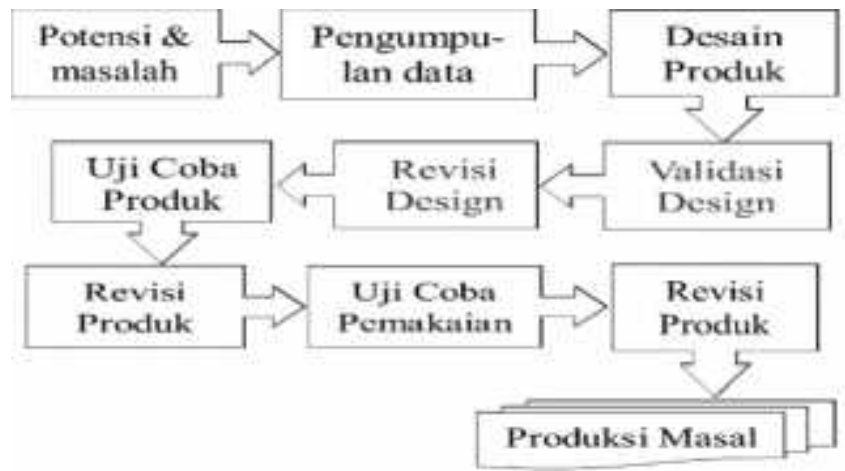

Gambar 1. Alur Metode R\&D (Sugiyono, 2015)

Validitas media diperoleh dari lembar validasi isi dan lembar validasi konstruk. Pada tahap validasi dilakukan oleh 3 orang ahli meliputi 2 dari dosen pendidikan kimia dan 1 dari guru kimia MA Roudlotun Nasyiin. Analisis data validasi dilakukan dengan menghitung skor total yang disesuaikan dengan skala likert yang memiliki nilai dari 1 hingga 5 (Riduwan, 2018). Kemudian dihitung menggunakan rumus berikut :

$$
\mathrm{P} \%=\frac{\text { zekor yuag auperoien }}{\text { SkOr Kriterie }} 100 \%
$$

Media interaktif dapat dinyatakan valid jika diperoleh persentase mencapai $\succeq 61 \%$. Kepraktisan media diperoleh dari lembar observasi dan lembar respon peserta didik. Analisis data hasil observasi dan hasil respon dilakukan menggunakan skala Guttman dengan nilai 
satu (1) untuk kategori Ya dan nilai nol (0) untuk kategori Tidak (Riduwan, 2018). Kemudian dihitung dengan rumus berikut :

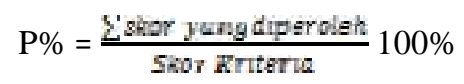

Media interaktif dapat dinyatakan praktis apabila persentase mencapai $\succeq 61 \%$. Keefektifan dilihat dari data hasil pergeseran miskonsepsi peserta didik dari miskonsepsi menjadi paham konsep. Analisis pergeseran miskonsepsi peserta didik menggunakan tes diagnostic three tier. Tes diagnostic three tier terdiri dari 3 tingkat. (1) pilihan jawaban peserta didik, (2) pilihan alasan, (3) tingkat keyakinan peserta didik dalam memilih jawaban (Azura and Copriady, 2017). Kategori klasifikasi konsepsi peserta didik dituliskan pada Tabel 1.

Tabel 1. Klasifikasi Konsepsi Soal 3 Tingkat

(Kustiarini, Susanti VH and Saputro, 2019)

\begin{tabular}{ccccc}
\hline $\begin{array}{c}\text { Tingkat 1 } \\
\text { (Jawaban) }\end{array}$ & $\begin{array}{c}\text { Tingkat 2 } \\
\text { (Alasan) }\end{array}$ & $\begin{array}{c}\text { Tingkat 3 } \\
\text { (Keyakinan) }\end{array}$ & Kategori & Singkatan \\
\hline Benar & Benar & Yakin & Tahu Konsep & TK \\
Benar & Salah & Yakin & Miskonsepsi 1 & MK1 \\
Salah & Benar & Yakin & Miskonsepsi 2 & MK2 \\
Salah & Salah & Yakin & Miskonsepsi 3 & MK3 \\
Benar & Benar & Tidak Yakin & Tidak tahu konsep & TTK \\
Benar & Salah & Tidak Yakin & Tidak tahu konsep & TTK \\
Salah & Benar & Tidak Yakin & Tidak tahu konsep & TTK \\
Salah & Salah & Tidak Yakin & Tidak tahu konsep & TTK \\
\hline
\end{tabular}

Rumus yang digunakan untuk analisis pergeseran miskonsepsi sebagai berikut :

$$
\mathrm{P} \%=\frac{\sum[M-\pi K]}{\sum(M \operatorname{Gral})} 100 \%
$$

(M-TK) : pergeseran dari miskonsepsi menjadi tahu konsep

(M awal) : miskonsepsi awal

Media interaktif dapat dinyatakan efektif jika persentase mencapai $\ 61 \%$.

\section{Hasil Penelitian dan Pembahasan}

Hasil analisis dan pembahasan pengembangan media pembelajaran interaktif C-Bonds dengan metode $\mathrm{R} \& \mathrm{D}$ dijabarkan sebagai berikut :

\section{a) Potensi Masalah}

Diantara masalah yang berpotensi muncul pada suatu pembelajaran yaitu miskonsepsi. Banyak sekali peserta didik yang masih mengalami miskonsepsi. Miskonsepsi yang dialami masing-masing peserta didik terjadi karena penyebab yang berbeda, diantaranya berasal dari prakonsepsi peserta didik, ketidaksesuaian tahap perkembangan kognitif dengan konsep, keterbatasan penalaran peserta didik, kemampuan peserta didik dalam menangkap dan memahami konsep (Yuliati, 2017). Miskonsepsi juga disebabkan karena kelemahan peserta didik dalam menghubungkan antara ketiga representasi level ilmu kimia (Sabekti, 2015).

\section{b) Pengumpulan Data}

Studi literatur yang dilakukan mengenai penelitian membahas tentang miskonsepsi pada materi ikatan kimia. Di MAN 5 Kediri siswa yang menderita miskonsepsi pada konsep ikatan ion sebesar 70,67\%, ikatan kovalen sebesar 69,33\%, dan ikatan kovalen koordinasi sebesar 75,33\% (Kumalaningtias, 2019). Di SMA Negeri 4 Sidoarjo siswa yang menderita miskonsepsi pada materi ikatan kimia sebesar 41\% (Sari and Nasrudin, 2015). Di SMA Negeri 9 Pontianak terdapat 19,8\% siswa yang menderita miskonsepsi pada materi ikatan kimia (Rahman, Eny and Erlina, 2014). 


\section{c) Desain Produk}

Pada tahap desain produk, peneliti membuat soal pre-test dan post-test, menyusun materi dan langkah-langkah conceptual change text, dan merancang desain media interaktif yang mana nanti berisi soal pretest dan posttest dan materi ikatan kimia. Media Interaktif C-Bonds didesain menggunakan aplikasi Adobe Flash action script (as) 3.0. Berikut penjelasan desain media interaktif C-Bonds.

1) Halaman Awal

Pada halaman awal terdapat judul media dan tombol start untuk memulai. Untuk menggunakan media, peserta didik harus menekan tombol start. Halaman awal ditampilkan oleh Gambar 2.

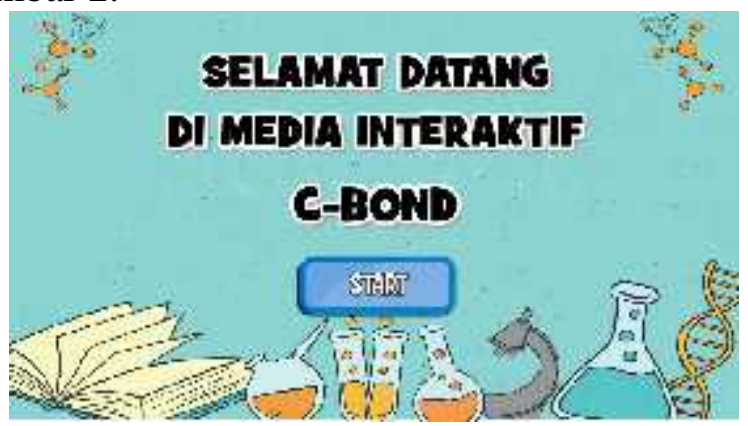

2) Petunjuk

\section{Gambar 2. Halaman Awal Media Interaktif C-Bonds}

Peserta didik yang telah memulai media interaktif akan diarahkan ke halaman petunjuk. Halaman petunjuk terdapat macam-macam tombol dan kegunaannya untuk memudahkan peserta didik menggunakan media interaktif. Halaman petunjuk ditampilkan oleh Gambar 3.

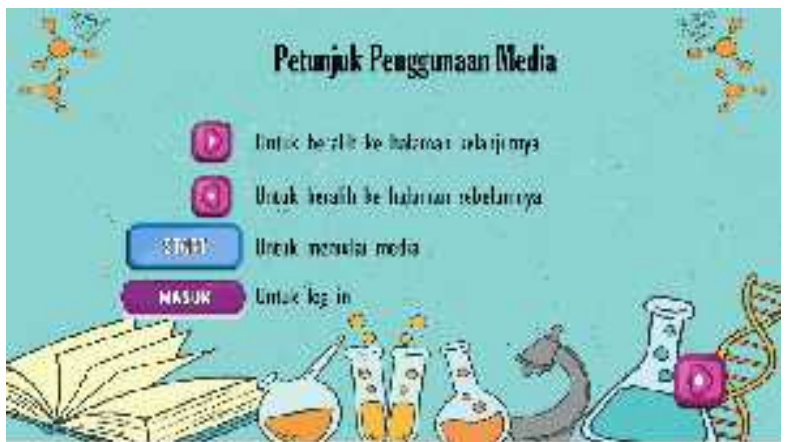

3) Informasi

\section{Gambar 3. Halaman Petunjuk Media Interaktif C-Bonds}

Pada halaman informasi berisi informasi mengenai pengertian dan tujuan media CBonds. Halaman Informasi ditampilkan oleh Gambar 4.

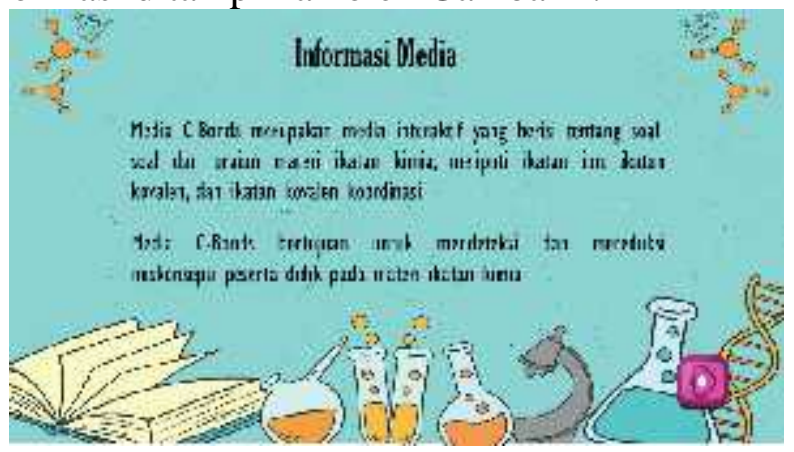

\section{Gambar 4. Halaman Informasi Media Interaktif C-Bonds}


4) Halaman Log in

Terdapat kolom nama, nomor absen, dan kelas pada halaman ini, dimana peserta didik harus mengisi data diri tersebut untuk bisa memulai media. Halaman login ditampilkan oleh Gambar 5.

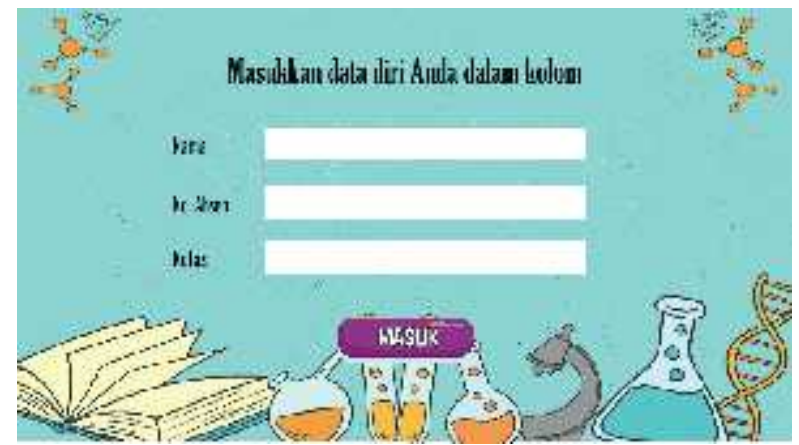

5) Soal Pretest dan Posstest

\section{Gambar 5. Halaman Login Media Interaktif C-Bonds}

Soal pretest berfungsi untuk mendeteksi miskonsepsi pada peserta didik menggunakan multiple choice three tier. (1) pilihan jawaban peserta didik, (2) pilihan alasan, (2) tingkat keyakinan peserta didik dalam memilih jawaban (Azura and Copriady, 2017). Setelah mengerjakan pretest akan keluar hasil konsepsi peserta didik dan melanjutkan ke tahap selanjutnya. Soal posttest bertujuan untuk mengetahui pergeseran konsepsi peserta didik setelah menyelesaikan CCT. Halaman soal pretest dan posstest ditunjukkan pada Gambar 6.

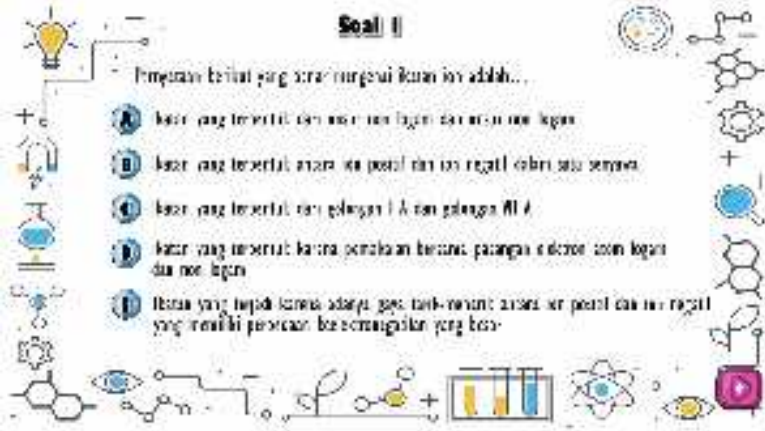

6) Conceptual Change Text

\section{Gambar 6. Tampilan Soal Pretest dan Soal Posttest}

Pada tahap ini bertujuan untuk menyembuhkan miskonsepsi dan ketidakpahaman peserta didik yang teridentifikasi setelah mengerjakan soal pretest. Terdapat 4 fase atau struktur dalam strategi conceptual change, yaitu : (1) menunjukkan konsep awal peserta didik, (2) membuat konflik kognitif terhadap konsepsi peserta didik, (3) Proses equilibrasi atau penjelasan konsep yang benar, (4) rekontruksi konsep (Perdana, Suma and Pujani, 2018). Halaman CCT ditunjukkan pada Gambar 7.

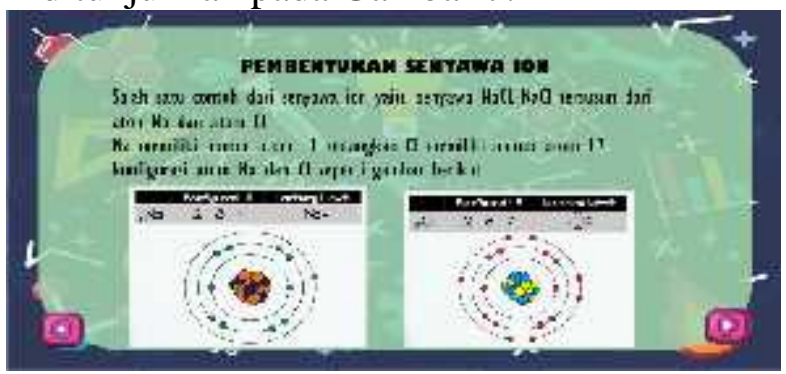

Gambar 7. Tampilan CCT Media Interaktif C-Bonds 
7) Pergeseran Konsep Peserta Didik

Pada bagian pergeseran miskonsepsi terdapat informasi konsepsi peserta didik setelah mengerjakan soal pretest dan posttest masing-masing konsep. Halaman pergeseran konsep ditunjukkan pada Gambar 9.

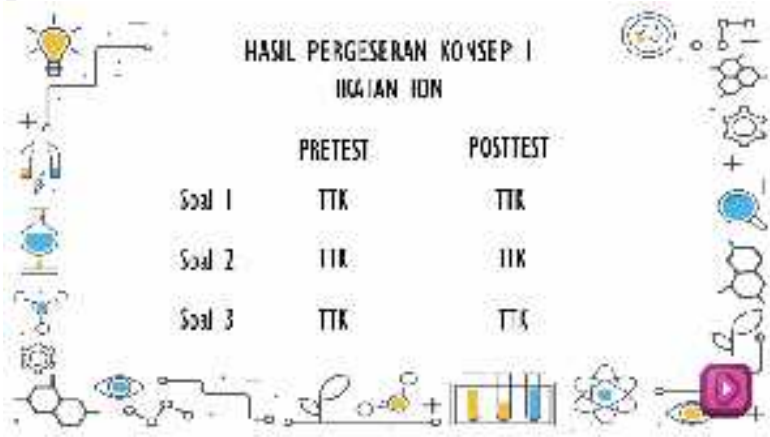

\section{d) Validasi Desain Produk}

\section{Gambar 8. Tampilan Pergeseran Konsep Peserta didik}

Validasi desain mencakup validasi isi dan konstruk. Pada tahap validasi dilakukan oleh 3 ahli meliputi 2 dari dosen pendidikan kimia dan 1 dari guru kimia MA Roudlotun Nasyiin. Hasil validasi isi ditunjukkan pada Tabel 2 dan validasi konstruk ditunjukkan pada Tabel 3.

Tabel 2. Validasi Isi Media Interaktif C-Bonds

\begin{tabular}{lccc}
\hline \multicolumn{2}{c}{ Aspek yang dinilai } & Persentase (\%) & Kategori \\
\hline $\begin{array}{l}\text { Mengetahui kesesuaian soal dan materi dalam media } \\
\text { interaktif }\end{array}$ & $93,33 \%$ & Sangat Valid \\
$\begin{array}{l}\text { Mengetahui kesesuaian } \\
\text { miskonsepsi peserta didik }\end{array}$ & & $91,66 \%$ & Sangat Valid \\
\begin{tabular}{l} 
Persentase rata-rata \\
\hline
\end{tabular} & $92,59 \%$ & Sangat Valid \\
\hline
\end{tabular}

Pada Tabel 2 di atas terdiri dari 2 aspek. Aspek pertama memiliki persentase 93,33\% yang mana dapat dikategorikan sangat valid. Sedangkan, aspek kedua memiliki persentase sebesar 91,66\% yang mana dapat dikategorikan sangat valid. Didapatkan persentase rata-rata dari kedua aspek tersebut yaitu 92,59\% sehingga dapat dikategorikan sangat valid.

\section{Tabel 3. Validasi Konstruk Media Interaktif C-Bonds}

\begin{tabular}{lcc}
\hline \multicolumn{1}{c}{ Aspek yang dinilai } & Persentase (\%) & Kategori \\
\hline Mengetahui kelayakan penyajian pada media interaktif & $89,33 \%$ & Sangat Valid \\
Mengetahui penggunaan bahasa pada media interaktif & $93,33 \%$ & Sangat Valid \\
Mengetahui kualitas grafis pada media interaktif & $91,66 \%$ & Sangat Valid \\
Persentase rata-rata & $91,44 \%$ & Sangat Valid \\
\hline
\end{tabular}

Pada Tabel 3 di atas terdiri dari 3 aspek. Aspek pertama memiliki persentase 89,33\% yang mana dapat dikategorikan sangat valid kategori sangat valid. Aspek kedua memiliki persentase 93,33\% yang mana dapat dikategorikan sangat valid. Aspek ketiga memiliki persentase $91,66 \%$ yang mana dapat dikategorikan sangat valid. Didapatkan persentase ratarata dari ketiga aspek tersebut yaitu 91,44\% sehingga dapat dikategorikan sangat valid. Berdasarkan dari hasil validasi isi dan validasi konstruk, media interaktif C-Bonds dapat dikatakan layak sebagai media pereduksi miskonsepsi peserta didik.

\section{e) Revisi Desain}

Pada tahap revisi desain dilakukan berdasarkan saran dan komentar dari validator. Berikut beberapa hal yang perlu diperbaiki yaitu :

1) Lembar observasi aktivitas peserta didik lebih dijabarkan lagi bagian-bagiannya dalam satu sub konsep

2) Menambahkan video terkait materi setiap sub konsep 
3) Menambahkan animasi bergerak pada materi CCT

f) Uji Coba Produk

Media diuji-cobakan pada 12 peserta didik kelas XI MA Roudlotun Nasyiin. Tahap uji coba dilakukan untuk mengetahui kepraktisan dan keefektifan media interaktif C-Bonds. Kepraktisan media interaktif dapat diketahui dari angket respon dan observasi aktivitas peserta didik. Hasil angket respon peserta didik dijabarkan pada Tabel 4. Sedangkan hasil observasi peserta didik dijabarkan pada Tabel 5 .

Tabel 4. Data Respon Peserta Didik

\begin{tabular}{lcc}
\hline \multicolumn{1}{c}{ Aspek yang dinilai } & Persentase (\%) & Kategori \\
\hline Ketertarikan peserta didik terhadap media interaktif & $94,44 \%$ & Sangat Praktis \\
Kemudahan penggunaan media interaktif & $91,66 \%$ & Sangat Praktis \\
Kejelasan bahasa pada media interaktif & $91,66 \%$ & Sangat Praktis \\
Motivasi belajar peserta didik menggunakan media & $87,5 \%$ & Sangat Praktis \\
interaktif & & \\
Persentase rata-rata & $91,31 \%$ & Sangat Praktis \\
\hline
\end{tabular}

Pada Tabel 4 terdiri dari 4 aspek yang di nilai. Persentase aspek pertama sampai keempat berturut-turut yaitu $94,44 \%$; $91,66 \% ; 91,66 \% ; 87,5 \%$ yang termasuk dalam kategori sangat praktis. Berdasarkan keempat aspek tersebut didapatkan persentase rata-rata sebesar $91,31 \%$ sehingga dapat dikatakan sangat praktis.

Dari data yang diuraikan di atas, ketertarikan peserta didik terhadap media sangat tinggi, serta peserta didik mudah dalam mengoperasikan media interaktif dan memahami bahasa yang digunakan pada media interaktif. Masing-masing aspek sesuai dengan karakteristik media yang baik, yaitu mampu memotivasi peserta didik, mudah penggunaannya, dan mampu memunculkan interaktivitas (Prastya, 2016). Selain itu, motivasi belajar peserta didik juga besar.

Tabel 5. Observasi Aktivitas Peserta Didik

\begin{tabular}{lcc}
\hline \multicolumn{1}{c}{ Aspek yang diamati } & Persentase (\%) & Kategori \\
\hline Kepraktisan media interaktif secara umum & $93 \%$ & Sangat Praktis \\
$\begin{array}{l}\text { Kepraktisan media interaktif pada konsep ikatan ion } \\
\text { Kepraktisan media interaktif pada konsep ikatan } \\
\text { kovalen }\end{array}$ & $96,87 \%$ & Sangat Praktis \\
$\begin{array}{l}\text { Kepraktisan media interaktif pada konsep ikatan } \\
\text { kovalen koordinasi }\end{array}$ & $96,87 \%$ & Sangat Praktis \\
Persentase rata-rata & $95,39 \%$ & Sangat Praktis \\
\hline
\end{tabular}

Pada Tabel 5 terdapat 4 aspek yang diamati oleh observer. Berdasarkan Tabel 5 didapatkan persentase rata-rata dari keempat aspek tersebut sebesar 95,39\% sehingga dapat dikategorikan sangat praktis. Peserta didik dapat mengoperasikan media dengan baik, mengerjakan soal pretest dan posttest dengan baik. Selain itu, peserta didik mengerjakan strategi CCT dengan runtut.

Keefektifan media interaktif dapat dilihat dari hasil pergeseran miskonsepsi yang diderita peserta didik, berawal dari miskonsepsi menuju tahu konsep. Hasil pergeseran konsepsi didapatkan dari soal pre-test dan post-test yang telah dikerjakan. Hasil pergeseran konsepsi sub konsep ikatan ion dijabarkan pada Tabel 6

Tabel 6. Pergeseran Konsepsi Sub Konsep Ikatan Ion

\begin{tabular}{|c|c|c|c|c|}
\hline \multirow{2}{*}{ Pergeseran Konsepsi } & \multicolumn{3}{|c|}{ Soal } & Total \\
\hline & 1 & 2 & 3 & \\
\hline TK-TK & 1 & 0 & 1 & \\
\hline
\end{tabular}




\begin{tabular}{|c|c|c|c|c|}
\hline TK-MK & 0 & 0 & 0 & 0 \\
\hline TK-TTK & 0 & 0 & 0 & 0 \\
\hline MK-TK & 7 & 11 & 8 & 26 \\
\hline MK-MK & 3 & 0 & 3 & 6 \\
\hline MK-TTK & 0 & 0 & 0 & 0 \\
\hline TTK-TK & 1 & 1 & 0 & 2 \\
\hline TTK-MK & 0 & 0 & 0 & 0 \\
\hline TTK-TTK & 0 & 0 & 0 & 0 \\
\hline
\end{tabular}

Pada Tabel 6 dapat dilihat bahwa pada sub konsep ikatan ion peserta didik yang mengalami pergeseran miskonsepsi dari TK-TK berjumlah 2, MK-TK berjumlah 26, MKMK berjumlah 6, dan TTK-TK berjumlah 2. Peserta didik yang mengalami pergeseran miskonsepsi telah melewati tahap CCT dan memahami konsep dengan benar. Hal tersebut terbukti bahwa CCT efektif untuk mereduksi miskonsepsi peserta didik (McKenna, 2014). Sedangkan, peserta didik yang kesulitan saat memahami konsep abstrak maka akan tetap menderita miskonsepsi (Sugiyantoro, 2020). Dari data tersebut total peserta didik yang mengalami miskonsepsi awal yaitu berjumlah 32, sehingga didapatkan persentase pergeseran konsepsi sebesar $81,25 \%$ dengan kategori sangat efektif. Berikutnya hasil pergeseran konsepsi sub konsep ikatan kovalen dijabarkan pada Tabel 7

\begin{tabular}{|c|c|c|c|c|}
\hline \multirow{2}{*}{ Pergeseran Konsepsi } & \multicolumn{3}{|c|}{ Soal } & \multirow[t]{2}{*}{ Total } \\
\hline & $\mathbf{1}$ & 2 & 3 & \\
\hline TK-TK & 1 & 0 & 2 & 3 \\
\hline TK-MK & 0 & 0 & 0 & 0 \\
\hline TK-TTK & 0 & 0 & 0 & 0 \\
\hline MK-TK & 8 & 11 & 6 & 25 \\
\hline MK-MK & 1 & 0 & 1 & 2 \\
\hline MK-TTK & 0 & 0 & 1 & 1 \\
\hline TTK-TK & 2 & 1 & 2 & 5 \\
\hline TTK-MK & 0 & 0 & 0 & 0 \\
\hline TTK-TTK & 0 & 0 & 0 & 0 \\
\hline \multicolumn{5}{|c|}{ 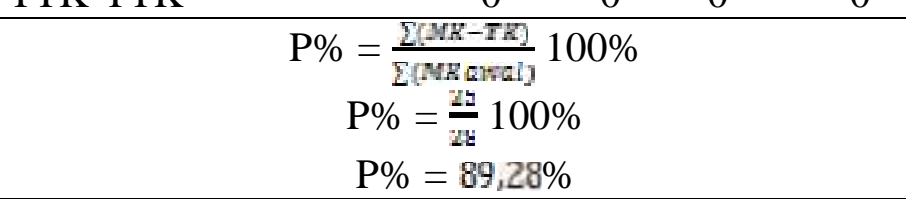 } \\
\hline
\end{tabular}

Pada Tabel 7 dapat dilihat bahwa pada sub konsep ikatan kovalen peserta didik yang mengalami pergeseran miskonsepsi dari TK-TK berjumlah 3, MK-TK berjumlah 25, MKMK berjumlah 2, MK-TTK berjumlah 1, dan TTK-TK berjumlah 5. Peserta didik yang mengalami pergeseran miskonsepsi telah melewati tahap CCT dan memahami konsep dengan benar. Hal tersebut terbukti bahwa CCT efektif untuk mereduksi miskonsepsi peserta didik (McKenna, 2014). Sedangkan, peserta didik yang kesulitan saat memahami konsep abstrak maka akan tetap menderita miskonsepsi (Sugiyantoro, 2020). Dari data tersebut total peserta didik yang mengalami miskonsepsi awal yaitu berjumlah 28 , sehingga didapatkan persentase pergeseran konsepsi sebesar 89,28\% dengan kategori sangat efektif. Berikutnya hasil pergeseran konsepsi sub konsep ikatan kovalen koordinasi dijabarkan pada Tabel 8 
Tabel 8. Hasil Pergeseran Konsepsi Sub Konsep Ikatan Kovalen Koordinasi

\begin{tabular}{|c|c|c|c|c|}
\hline \multirow{2}{*}{ Pergeseran Konsepsi } & \multicolumn{3}{|c|}{ Soal } & \multirow[t]{2}{*}{ Total } \\
\hline & 1 & 2 & 3 & \\
\hline TK-TK & 2 & 0 & 2 & 4 \\
\hline TK-MK & 0 & 0 & 0 & 0 \\
\hline TK-TTK & 0 & 0 & 0 & 0 \\
\hline MK-TK & 8 & 10 & 10 & 28 \\
\hline MK-MK & 0 & 2 & 0 & 2 \\
\hline MK-TTK & 0 & 0 & 0 & 0 \\
\hline TTK-TK & 2 & 0 & 0 & 2 \\
\hline TTK-MK & 0 & 0 & 0 & 0 \\
\hline TTK-TTK & 0 & 0 & 0 & 0 \\
\hline \multicolumn{5}{|c|}{$\begin{array}{c}\mathrm{P} \%=\frac{\sum(M N-T K)}{\sum(M K \text { awai })} 100 \% \\
\mathrm{P} \%=\frac{2 \mathrm{y}}{a v} 100 \% \\
\mathrm{P} \%=93,33 \% \%\end{array}$} \\
\hline
\end{tabular}

Pada Tabel 8 dapat dilihat bahwa pada sub konsep ikatan kovalen koordinasi peserta didik yang mengalami pergeseran miskonsepsi dari TK-TK berjumlah 4, MK-TK berjumlah 28, MK-MK berjumlah 2, dan TTK-TK berjumlah 2. Peserta didik yang mengalami pergeseran miskonsepsi telah melewati tahap CCT dan memahami konsep dengan benar. Hal tersebut terbukti bahwa CCT efektif untuk mereduksi miskonsepsi peserta didik (McKenna, 2014). Sedangkan, peserta didik yang kesulitan saat memahami konsep abstrak maka akan tetap menderita miskonsepsi (Sugiyantoro, 2020). Dari data tersebut total peserta didik yang mengalami miskonsepsi awal yaitu berjumlah 30, sehingga didapatkan persentase pergeseran konsepsi sebesar 93,33\% dengan kategori sangat efektif yang artinya media interaktif CBonds efektif untuk mereduksi miskonsepsi peserta didik.

Media pembelajaran interaktif C-Bonds dapat memvisualisasikan materi ikatan kimia yang bersifat abstrak dengan baik sehingga memudahkan peserta didik dalam memahami materi ikatan kimia. Selain itu, dapat mereduksi miskonsepsi peserta didik. Penggunaan media pembelajaran interaktif dapat dikatakan efektif dalam membantu peserta didik belajar dan meningkatkan pemahaman konsep peserta didik (Zukhruf, Kana Dhiean; Khaldun, Ibnu; Ilyas, 2016). Media pembelajaran interaktif C-Bonds didesain menggunakan aplikasi Adobe Flash action script 3 yang mana mudah diakses, baik dilaptop maupun di komputer. Penggunaannya juga tidak memerlukan LAN yang hanya terbatas pada beberapa laptop sehingga tidak begitu membutuhkan WiFi untuk menjangkau dalam jumlah yang lebih banyak dan dalam waktu yang bersamaan (Sugiyantoro, 2020).

\section{Kesimpulan}

Berdasarkan dari penelitian yang telah dilakukan, Media Interaktif C-Bonds yang dikembangkan dapat dikatakan layak sebagai media interaktif untuk mendeteksi dan mereduksi miskonsepsi peserta didik ditinjau dari 3 hal, yaitu: (1) Kevalidan media interaktif C-Bonds ditinjau dari validasi isi dan validasi konstruk. Persentase validasi isi sebesar 92,59\% dan validasi konstruk sebesar 91,44\%. Keduanya dikategorikan sangat valid. (2) Kepraktisan media interaktif ditinjau dari angket respon dan observasi. Persentase angket respon sebesar 91,31\% dan observasi sebesar 95,39\%. Keduanya dikategorikan sangat praktis (3) Keefektifan media interaktif dilihat dari hasil pergeseran miskonsepsi yang awalnya miskonsepsi menjadi paham konsep, diperoleh hasil sebesar 87,95\% dengan kategori sangat efektif. 


\section{Saran}

Beberapa saran yang dapat disampaikan dalam penelitian ini yaitu penelitian dengan metode R\&D hanya sampai langkah uji coba terbatas. Selain itu, media interaktif yang dikembangkan hanya dapat digunakan pada materi ikatan kimia. Saran khusus kepada guru yaitu Media Interaktif C-Bonds yang dikembangkan dapat digunakan sebagai alternatif media untuk mendeteksi dan mereduksi miskonsepsi, sehingga guru dapat lebih mudah membimbing peserta didik untuk memahami konsep yang berkelanjutan. Selain itu, guru harus memperhatikan ketersediaan jumlah perangkat komputer dengan jumlah peserta didik. Dari beberapa hal tersebut, maka perlu adanya penelitian yang lebih lanjut untuk menyempurnakan penelitian ini.

\section{Daftar Pustaka}

Alfiana, R. and Sukarmin (2019) 'Pengembangan Multimedia Berbasis Komputer untuk Mengurangi Miskonsepsi Siswa pada Materi Kesetimbangan Kimia Kelas XI SMA', UNESA Journal of Chemical Education, 5(3), pp. 689-695.

Armagan, F. O., Keskin, M. O. and Akin, B. S. (2010) 'Effectiveness of conceptual change texts: A Meta analysis', in Procedia - Social and Behavioral Sciences, pp. 15741579. doi: 10.1016/j.sbspro.2010.12.367.

Azura, S. and Copriady, J. (2017) 'Identifikasi Miskonsepsi Materi Ikatan Kimia Menggunakan Tes Diagnostik Pilihan Ganda Tiga Tingkat (Three Tier) pada Peserta Didik Kelas X MIA SMA Negeri 8 Pekanbaru', Jurnal Online Mahasiswa, 4(3), pp. $1-13$.

Hesti, R. et al. (2017) 'Conceptual Change Text ( CCT ) dalam Mengubah Konsepsi Rangkaian Listrik Paralel Siswa', (October 2018).

Kumalaningtias, R. S. (2019) 'Pengembangan Software Anti Misconception of Chemical Bonding (Mcb) Dengan Strategi Conceptual Change Text Untuk Mereduksi Miskonsepsi Pada Materi Ikatan Kimia', UNESA Journal of Chemical Education, 8(3), pp. 420-426.

Kustiarini, F. T., Susanti VH, E. and Saputro, A. N. C. (2019) 'Penggunaan Tes Diagnostik Three-Tier Test Alasan Terbuka untuk Mengidentifikasi Miskonsepsi Larutan', Jurnal Pendidikan Kimia, 8(2), p. 171. doi: 10.20961/jpkim.v8i2.25236.

McKenna, D. M. (2014) Using Conceptual Change Texts to Address Misconceptions in the Middle School Science Classroom.

Medina, P. (2017) 'Analisis Miskonsepsi Siswa kelas X pada Materi Larutan Elektrolit dan Non Elektrolit serta Reaksi Oksidasi dan Reduksi dalam Pembelajaran Kimia di SMAN 10 Kota Padang', Journal Of Residu, 1(1), pp. 73-84.

Nahum, T. L. et al. (2010) 'Teaching and learning the concept of chemical bonding', Studies in Science Education, 46(2), pp. 179-207. doi: 10.1080/03057267.2010.504548.

Perdana, G. P., Suma, K. and Pujani, N. M. (2018) 'The effect of conceptual change text on improving student understanding of electricity concepts and learning motivation', International Research Journal of Engineering, IT \& Scientific Research, 00075. doi: 10.21744/irjeis.v4n6.337.

Prastya, A. (2016) 'Strategi pemilihan media pembelajaran bagi seorang guru', in Media Jurnal Kependidikan Vol. 7, No. 4 (Desember 2021) 
Pembelajaran, pp. 294-302. Available at: http://repository.ut.ac.id/id/eprint/6518.

Rahman, A., Eny, E. and Erlina (2014) 'Miskonsepsi Siswa Kelas XI IPA SMA Negeri 9 Pontianak Pada Materi Ikatan Kimia', Jurnal Pendidikan dan Pembelajaran, 3(10), pp. 1-13.

Riduwan (2018) Skala Pengukuran Variabel-variabel Penelitian. Bandung: Alfabeta.

Sabekti, A. W. (2015) Miskonsepsi siswa dalam bidang studi kimia: faktor penyebab dan solusinya.

Sari, M. W. and Nasrudin, H. (2015) 'Penerapan Model Pembelajaran Conceptual Change Untuk Mereduksi Miskonsepsi Siswa Pada Materi Ikatan Kimia Kelas X SMA Negeri 4 Sidoarjo', UNESA Journal of Chemical Education, 4(2), pp. 315-324.

Sirhan, G. (2007) 'Sirhan / TÜFED-TUSED / 4(2) 20072 Learning Difficulties in Chemistry: An Overview', Journal of TURKISH SCIENCE EDUCATION, 4(2), pp. 2-20. Available at: http://www.tused.org.

Sugiyantoro, F.; S. (2020) 'PENGEMBANGAN SOFTWARE ANTI MISCHEM UNTUK MEREDUKSI MISKONSEPSI SISWA DENGAN STRATEGI CONCEPTUAL CHANGE TEXT PADA MATERI ASAM BASA KELAS XI SMA DEVELOPMENT OF SOFTWARE ANTI MISCHEM FOR REDUCING MISCONCEPTION OF STUDENTS WITH STRATEGIES CONCEPTUAL CHANGE TE', UNESA Journal of Chemical Education, 9(3), p. 27436.

Sugiyono (2015) Metode Penelitian Kuantitatif, Kualitatif, dan $R \& D$. Bandung: Alfabeta.

Sukarmin, Z. (2020) 'Pengembangan Software Anti Mischem Untuk Mereduksi Miskonsepsi Peserta Didik Pada Materi Hidrolisis Garam Dengan Strategi Conceptual Change Text Development of Software Anti Mischem To Reduce Misconception of Students in Hydrolysis of Salt With Conceptual', UNESA Journal of Chemical Education, 9(3), pp. 387-396.

Syahrul, D. A. et al. (2015) 'Identifikasi Miskonsepsi dan Penyebab Miskonsepsi Siswa dengan Three-tier Diagnostic Test Pada Materi Dinamika Rotasi Dimas Adiansyah Syahrul, Woro Setyarsih', Jurnal Inovasi Pendidikan Fisika, 04(03), pp. 67-70.

Widarti, H. R., Safitri, A. F. and Sukarianingsih, D. (2018) 'Identifikasi Pemahaman Konsep Ikatan Kimia', J-PEK (Jurnal Pembelajaran Kimia), 3(1), pp. 41-50. doi: 10.17977/um026v3i12018p041.

Yahya, F., Fatoni, A. and Walidain, S. N. (2018) 'Pengembangan Multimedia Pembelajaran Interaktif Model Tutorial Berbasis Adobe Flash Materi Cahaya Siswa Smp Kelas Viii', in, pp. 358-365. doi: 10.31227/osf.io/rq2ze.

Yuliati, Y. (2017) 'Miskonsepsi Siswa Pada Pembelajaran IPA Serta Remediasinya', Jurnal Bio Educatio, 2(2), pp. 50-58.

Zukhruf, Kana Dhiean; Khaldun, Ibnu; Ilyas, S. (2016) 'Remediasi Miskonsepsi Dengan Menggunakan Media Pembelajaran Interaktif Pada Materi Fluida Statis', Jurnal Pendidikan Sains Indonesia, 04(02), pp. 56-68. 